\title{
A Comparison of the Metaphorical Usage of the Word "Wisdom" in the Poems of Two Khorasanian Rational Poets Using Cognitive Linguistics
}

\author{
Atiyeh Kamyabi Gol ${ }^{1, *}$, Andisheh Ghadirian ${ }^{2}$ \\ ${ }^{1}$ Department of Linguistics, Faculty of Letters and Humanities, Ferdowsi University of Mashhad, Iran \\ ${ }^{2}$ Department of Persian Language and Literature, Faculty of Letters and humanities, Ferdowsi University of Mashhad, Iran
}

Copyright (C) 2015 by authors, all rights reserved. Authors agree that this article remains permanently open access under the terms of the Creative Commons Attribution License 4.0 International License.

\begin{abstract}
Cognitive semantics has paid a great deal of attention to the study of metaphor. In fact, metaphor is seen as a suitable tool for recognizing the manner of thinking and linguistic behaviors. In this approach, metaphor is one of the important tools for transmitting experience and mental concepts. In other words, in cognitive linguistics, a new meaning is bestowed upon metaphor. Therefore, metaphor refers to any understanding or expressing abstract concepts in terms of the concrete domains. The present article compared the metaphors related to the word "wisdom" in the poems of the two Khorasanian rational poets, Ferdowsi and Naser Khosrou. The aim of this article was to contemplate the place and value of wisdom in the works of these two rational poets. In order to do so, the lexical item "wisdom" was identified and extracted from the poems and then categorized based on the similarity of usage found in the poems.
\end{abstract}

Keywords Metaphor, Cognitive Semantics, Metaphorical Domains, Persian Literature, Naser Khosrou, Ferdowsi

\section{Introduction}

Expressing the value of wisdom- man's distinguishing criterion from beasts- has always been the focus of attention in various Persian poetry and prose. The most expressive Khorasani poets (poets living in the northeastern province of Khorasan, Iran) who have undertaken the responsibility of putting the limelight on wisdom are Abu Mo'in Nasir ibn Khusraw Qubadiani and Abū al-Qasem Ferdowsi Tousi. Without a doubt, the delicate eloquence that can be observed in the works of the above mentioned poets, represent the worldviews of the people of Khorasan and can therefore serve as a good source for acquaintance with the perception, culture, and traditions of these people.
Persian has always favored the use of figurative language $[5,28,31]$. The definition of metaphor has changed since it was first used in ancient Greece. Based on cognitive linguistics, metaphor no longer only applies to figurative language; it has evolved during the past decades and can now encompass a society's world view. The word metaphor comes from the Greek "meta-forein" = "to bring beyond". Metaphor aims to express something that is beyond a general and immediate understanding. "This occurs when certain distinct attributes of one object are attributed to the other, thus describing the latter with the qualities intrinsic to the former" $[1 ; \mathrm{P} .1]$.

With the remarkable advances made in the area of cognition during the past decades, cognitive linguistics is receiving a great deal of attention. It is worth mentioning that cognitive linguistics draws upon empirical findings from cognitive psychology. The aim of this field of linguistics is to explain "the mental processes that underlie the acquisition, storage, production and understanding of speech and writing" [4; P. 1]. Cognitive linguistics has many different features. Some of which have been outlined by Croft and Cruse (2004) include cognitive linguistics' denial that "there is an autonomous linguistic faculty in the mind; it understands grammar in terms of conceptualization; it claims that knowledge of language arises out of language use" (P. 1).

\subsection{The Rise of Cognitive Linguistics}

Cognitive linguistics is believed to be a more or less combination of incidents and research findings during the 1960s and 70s in the field of theoretical linguistics [9, 25, 29]. The vast areas of research ranged from the semantic analysis of grammar to conceptual analysis of literary language. It was during this time that various scholars such as Lakoff and Langacker came to realize that the linguistic theory of the time was missing a semantically based approach to grammar $[14,11,36]$. Therefore, the great change of the time was based on such views and this came 
as a reaction towards the Chomskyan generative approach to language. As Hilferty $(2001$, p. 2) sums up "Only in this way could a linguistic paradigm capture significant generalizations with any sort of credible claim to psychological plausibility".

In the early 1980s Cognitive linguistics was mainly practiced by a few scholars on the west of the United States and it began to expand in northern Europe and especially in Belgium, Germany, and Holland. Finally during 1990s, cognitive linguistics became widely known and practiced all throughout North America and Europe [7].

Cognitive linguistics is a main branch of second generation of cognitive science [31] and is an alliance of approaches in the last decade of the 20th century known as the Second Cognitive Revolution [13].

Proponents of cognitive linguistics assert that there is an intimate relationship between areas of cognition and language. In fact it is believed that metaphor and metonymy play a vital role in imaginative reasoning and concept formation [16, 17, 19, 20, 23, 24].

The two main commitments that help define cognitive linguistics include: 1 . the generalization commitment; and 2. the cognitive commitment. According to Lakoff (1990), the generalization commitment mainly refer to research based upon generalizations regarding all aspects of language; while the cognitive commitment relates to incorporating the results obtained from other cognitive sciences such as cognitive psychology, psycholinguistics, anthropology, etc. $[22,10]$. While the generalization commitment seems to be overwhelming in that "in practice, of course there is not enough time to study all the phenomena of any single language" $[18 ;$ p. 1$]$, the cognitive commitment seems to have a more realistic and practical demand.

\subsection{Historical Overview on Metaphor and Metaphor Research}

The concept of metaphor has been controversial back to the time of Aristotle. He explained metaphor on the level of noun, declaring that metaphor generally happens to the noun:

...the application of a strange (alien, allotrios) term either transferred (displaced, epiphora) from the genus and applied to the species or from the species and applied to the genus, or from one species to another, or else by analogy (1982:1447b).

Aristotle asserts that whenever we name something that might be alien to us, it may help in clarifying and simplifying that alien idea for us. Aristotle gives four possibilities regarding how to create a metaphor. These possibilities include: genus to species, species to genus, species to species, and by analogy or proportion [10].

Metaphor and use of metaphor has many different advantages. In his book Rhetoric, Aristotle (1954) points out some of these virtues as facility, clarity, warmth, elegance and appropriateness and goes on to assert "metaphor sets the scene before our eyes" (p. 1410b).
Metaphors have become so much a part of the ordinary language that instead of "contending that they deviate from a normative grammar, it is worth considering that any grammar, which cannot account for metaphor, is too limited in comprehension to be useful" [27; p. 32]. Imre (2010) believes that it is indeed metaphors that reflect the differences between man and beast "by the systematicity of analogies and disanalogies" (p. 79).

The main reason behind the tremendous popularity of metaphor studies stems from cognitive linguistics. This specific fundamental strand of research was launched by Lakoff and Johnson in 1980. In cognitive linguistics it is believed that metaphor reflects ideologies, abstract thought patterns, imagination and the way one reasons in real life $[23,24,20,16,35,10,12,8,36]$. It should be kept in mind that the awesome power of metaphor comes from the fact that metaphors have a dual function "of reminding us of pervasive patterns of experience while alerting us to new conceptual and aesthetic possibilities" [11; p. 2]. Metaphor creates a connection between the human mind and language and it "cannot be investigated in isolation from human embodiment" [6; p. 44].

\subsection{Criticisms Regarding Cognitive Linguistic Research on Metaphor}

Although cognitive linguistic research on metaphor is very popular and a great deal of empirical data has been collected this way; however, it has not been void of criticisms. The main areas of criticism are regarding the methodological issues, novelty of metaphorical issues, theoretical questions, and finally ignoring other pragmatic information [11]. Let us focus more on each area of criticism.

The first criticism which is related to methodological aspects points several issues: 1 . How are cognitive linguists able to identify various metaphors; 2. How they infer between primary and conceptual metaphors and everyday language used by members of a society. 3. Analyses are generally based on more subjective intuition which "are often tied to theories/hypotheses they wish to support" [11; p. 10]. 4. There seems to be a lack of identification procedure that helps one determine conceptual metaphors.

The second area of criticism is related to the novelty of metaphors. How can one determine for sure whether a specific metaphor is novel or whether it has been used by others before? Again we have no specific identification method to use in this regard.

The third area involves the theoretical issues. In fact the most important criticism in this regard mentions whether "the fact that people use metaphor in language necessarily indicates that they are thinking metaphorically" $[11 ; \mathrm{p} .11]$ and the main reason to support this claim is that the linguistic analyses are usually post-hoc and subjective. While scientific theories are supposed to be predictive, linguistic analyses lack this feature.

The last criticism involves the notion that cognitive 
linguistic studies on metaphors are too focused on the metaphorical knowledge and they do not take into consideration other conceptual or pragmatic information that is used to interpret the meaning of each metaphor.

\section{Materials and Method}

Based on cognitive linguistics, human experience can be divided into two categories: 1. Empirical, and 2. Intuition. One of the central foci of cognitive linguistics is introducing abstract ideas based on concrete experiences. Many scholars such as Lakoff and Johnson (2003) assert that one appropriate method of expressing abstract ideas is through the use of metaphors. The type of metaphors used generally help with the overall understanding of the abstract themes and so help to make the ideas more concrete and palpable for the audience.

Iranian poets have always been fascinated by abstract concepts such as love, pursuit of happiness, wisdom, etc. and so such ideas are recurring themes in their poems. Various metaphors have been used to express the idea of wisdom in the poems of Abu Mo'in Nasir ibn Khusraw Qubadiani and Abū al-Qasem Ferdowsi Tousi. The idea of wisdom has been a recurring theme in their works. Due to the importance placed on this idea, it was decided that the various metaphors referring to wisdom be identified and categorized based on the similarities found in the poems.

Despite the researchers' attempts at finding an English translation of the exact verses, no comprehensive version was discovered. Therefore, the researchers took it upon themselves to provide an English translation of each metaphor and the verse it was used in. Initially all metaphors regarding wisdom were identified in each poet's poems and then the metaphors were categorized based on the similarity in the idea portrayed by the metaphor.

The categorization is first provided for each individual poet and is then followed by a comparison of the data attained from the two poets' use of metaphors on wisdom. Each metaphor domain elaborates on the possible metaphorical understanding of the two poets regarding the word "wisdom". How they manifest the metaphor reflects the social, cultural, religious and economic realities of their times.

\section{Findings and Discussion}

The first section of the results pertains to the metaphors found in Naser Khosrou's works. The results have been categorized in order to help with the overall comprehension of the metaphors. Each translated verse encompasses a bolded metaphor to help the reader. The specific reference in which the original verse (Persian) was found in is also mentioned after each verse. The original Persian verses were found in $[32,34]$. After each metaphor domain, a table including the statistical results will follow. Each of the domains reflects the thought patterns and prevalent ideas of the people in Naser Khosrou's era and in turn can help us have a better understanding of his time.

\section{Vegetation Domain}

Considering the fact that a great majority of Iranians have been farmers throughout time, it becomes clear why vegetation was selected as domain for the word "wisdom" by Naser Khosrou. Verses including "wisdom" are:

If your inner tree bears fruits of wisdom, then your being becomes valuable. If not, you become an Abel tree which bears no fruits.

A wise saying is the leaf on the wisdom branch, advice and council the vapor rising from the sea of oration.

If your inner seed is irrigated with the water of wisdom, the branches of your inner tree will grow till they reach Pleiades.

In the eyes of the sagacious, knowledgeable beings are considered the fruit of the world tree and the ignorant, the thorns.

Knowledge is a tree on which speech is the leaf and wisdom, a seed which bears speech as its fruit.

Your essence a tree, its fruit wisdom and speech the leaves. Your mortal body is the thorns.

Wisdom is the fruit of the tree of essence in man and the unwise, plan tree.

Oh, thou brilliant sapling (oh, man who has the potential to flourish and grow) if the tree of your essence bears no fruits of wisdom, then you are doomed to be a willow or Abel tree.

Clear your head of any vain thoughts for wisdom is a lily and it is unfit to leave lilies within garlic stem which has an unpleasant scent.

Your essence is soil and wisdom a rose or tulip seed. Soil is ornamented with colorful roses and tulips.

Table 1. Percentage and number of metaphors in the vegetation domain

\begin{tabular}{|c|c|c|}
\hline $\begin{array}{c}\text { Relative } \\
\text { Percentage }\end{array}$ & $\begin{array}{c}\text { Total Number of } \\
\text { Metaphors }\end{array}$ & $\begin{array}{c}\text { Items from Vegetation } \\
\text { Domain }\end{array}$ \\
\hline $10.41 \%$ & 96 & 10 \\
\hline
\end{tabular}

\section{Luminosity Domain}

Light, pursuit of light and knowledge have always recurring themes in Persian poetry. It is believed that through light man can find his creator and so this has great values in Persian Poetry. Here are the examples found in this regard:

Tread through the cool shades of religion. The universe is a desert with scorching pebbles. Rely on the candle of wisdom for the universe is a dark night.

Anyone who does not find the right path to theism through the candle of wisdom is misled and joins the unfaithful.

Everyone needs a guide and torch to tread the path of life. Choose righteous deeds as your guide and wisdom as your torch.

Heart is illuminated with wisdom; pain and drunkenness 
healed through it.

In order to tread through the path of life one needs a guide and torch. Choose righteous deeds as your guide and wisdom as your torch.

Light the candle of wisdom in your heart and with this luminous heart tread towards the bright world.

My heart was filled with light through wisdom and my drunkenness passed away by wisdom.

Table 2. Percentage and number of metaphors in the luminosity domain

\begin{tabular}{|c|c|c|}
\hline $\begin{array}{c}\text { Relative } \\
\text { Percentage }\end{array}$ & $\begin{array}{c}\text { Total Number of } \\
\text { Metaphors }\end{array}$ & $\begin{array}{c}\text { Items from Luminosity } \\
\text { Domain }\end{array}$ \\
\hline $7.29 \%$ & 96 & 7 \\
\hline
\end{tabular}

\section{Guidance and Reliance Domain}

The Sufi way of life which generally promotes following in the great masters' footsteps has greatly influenced Persian Poetry and in doing so a great number of metaphors were found to have this recurring theme:

If you wish to have a prudent outlook toward your deeds, wisdom will suffice as your council.

Religion and wisdom should be the commander in chief in the army of your essence so that the companion (God) might bestow upon you His rank of commander in chief.

There is no safe passage through the winding roads of life, unless man opts for wisdom as his guide.

In the path of life, wisdom is a true and sincere friend and tool; in the path of religion, a wise guide and a cane to rely on.

If wisdom be the precursor and predecessor of my army, no enemy can dare to attack.

Happiness and prosperity are the servants of those who obey the orders of wisdom.

Wisdom is an auspicious and fortunate cane which can guide man to prosperity and happiness.

Table 3. Percentage and number of metaphors in the guidance and reliance domain

\begin{tabular}{|c|c|c|}
\hline $\begin{array}{c}\text { Relative } \\
\text { Percentage }\end{array}$ & $\begin{array}{c}\text { Total Number of } \\
\text { Metaphors }\end{array}$ & $\begin{array}{c}\text { Items from Guidance and } \\
\text { Reliance Domain }\end{array}$ \\
\hline $7.29 \%$ & 96 & 7 \\
\hline
\end{tabular}

\section{Religion Domain}

It goes without saying that religion has always been a recurring domain in Naser Khosrou's poems. He chooses religion to elaborate on "wisdom" in the following verse:

The mislead beast of your essence can be guided back to Islam, if Solomon of wisdom be its council.

Wisdom-the prophet of God sent upon you- advises.

Table 4. Percentage and number of metaphors in the religion domain

\begin{tabular}{|c|c|c|}
\hline $\begin{array}{c}\text { Relative } \\
\text { Percentage }\end{array}$ & $\begin{array}{c}\text { Total Number of } \\
\text { Metaphors }\end{array}$ & $\begin{array}{c}\text { Items from Religion } \\
\text { Domain }\end{array}$ \\
\hline $2.08 \%$ & 96 & 2 \\
\hline
\end{tabular}

\section{Flesh and Physique Domain}

The human anatomy, how different organs work as a whole to achieve a bigger purpose are among the macro level understanding of the people of Naser Khosrou's time. He uses these ideas to elaborate on "wisdom":

His words, for the body of knowledge are, a head and for the eye of wisdom, a cure.

Oh Child! Wake from thou careless sleep and look upon the world through your open eye of wisdom.

If I can not open my eyes to wisdom in my youth, then alas! For it has gone in vain.

Do something that can contribute to the stature of your knowledge. Avoid paying close attention to superficial matters (such as the fabric of your attire) and also gluttony.

Table 5. Percentage and number of metaphors in the flesh and physique domain

\begin{tabular}{|c|c|c|}
\hline $\begin{array}{c}\text { Items from Flesh and } \\
\text { Physique Domain }\end{array}$ & $\begin{array}{c}\text { Total Number of } \\
\text { Metaphors }\end{array}$ & $\begin{array}{c}\text { Relative } \\
\text { Percentage }\end{array}$ \\
\hline 4 & 96 & $4.16 \%$ \\
\hline
\end{tabular}

\section{Birds Domain}

Love of nature and particularly birds can also be a domain to elaborate on the use of "wisdom":

Wisdom is the wing for man's soul; if you break this wing, you can never fly out of the deep well called world.

Interpretation is the wings of wisdom. Can any bird fly without wings?

With the falcon of your wisdom, hunt courtesy and grace; for courtesy and grace are the best preys for the falcon of wisdom .

Focus only on deeds wisdom advises you on, so that you can soar the sky.

Table 6. Percentage and number of metaphors in the birds domain

\begin{tabular}{|c|c|c|}
\hline Items from Birds Domain & $\begin{array}{c}\text { Total Number of } \\
\text { Metaphors }\end{array}$ & $\begin{array}{c}\text { Relative } \\
\text { Percentage }\end{array}$ \\
\hline 4 & 96 & $4.16 \%$ \\
\hline
\end{tabular}

\section{Evaluation Domain}

Sufi and religious thought patterns of personal evaluation are the prevalent features of this domain:

Wealth can only be defined as something that can never be decreased by expenditure. All that can be measured with the scale of wisdom have this feature.

If attaining mundane blessings be accompanied with pain and toil, it does not weigh much on the scale of wisdom (it is not worth much).

No one can act as the yardstick for my wisdom's scale weight, for it is your forbearance and grace that has given weight to my scale of wisdom.

Based on the criterion of wisdom, I am better in orating, contriving, and intelligence than you.

Do not accept any word unless it is judicious; for word is gold and wisdom is the scale.

Hear all words and weigh them using your scale of wisdom; for in my opinion, wisdom is the most important criterion of measuring good and evil. 
I will not breathe a word unless it is judicious; for wise words are gold and their value can only be measured with the scale of wisdom.

Table 7. Percentage and number of metaphors in the evaluation domain

\begin{tabular}{|c|c|c|}
\hline $\begin{array}{c}\text { Items from Evaluation } \\
\text { Domain }\end{array}$ & $\begin{array}{c}\text { Total Number of } \\
\text { Metaphors }\end{array}$ & $\begin{array}{c}\text { Relative } \\
\text { Percentage }\end{array}$ \\
\hline 7 & 96 & $7.29 \%$ \\
\hline
\end{tabular}

\section{Cleansing and Purification Domain}

Religious themes are the heart and soul of the following verses:

The soul has to be washed with the soap of wisdom; for man's mortal body would remain dirty and soiled if washed with ordinary soap.

Clothes are washed with soap and wisdom is like a large soap for the soul.

If you wash away evil and satanic characteristics with wisdom, you can change into a real human being.

Search for water of wisdom and with it chasten all ill-natured lines and wrinkles of your soul.

Why do you not wash away the impression of ignorance and foolishness from your face with wisdom? It is only through this that you might be freed from evil and satanic characteristics.

Why do you not purify your soul from all impurities with the fire of wisdom and through praying and worshipping God?

Table 8. Percentage and number of metaphors in the cleansing and purification domain

\begin{tabular}{|c|c|c|}
\hline $\begin{array}{c}\text { Items from Cleansing and } \\
\text { Purification Domain }\end{array}$ & $\begin{array}{c}\text { Total Number of } \\
\text { Metaphors }\end{array}$ & $\begin{array}{c}\text { Relative } \\
\text { Percentage }\end{array}$ \\
\hline 6 & 96 & $6.25 \%$ \\
\hline
\end{tabular}

\section{Jewelry and Attire Domain}

Referring to garments, jewelry and royal attire has given an exalted position to "wisdom":

If there be no attire to cover this mortal body, I would wrap the garment of wisdom around my body.

Silk, gold, and silver garments are women's accessories; Men's however should be knowledge and wisdom.

Draw patterns of wisdom on your heart; for wisdom is the best ornament for the heart.

You have to embellish yourself with knowledge and wisdom, and not with a throne and crown.

If you place wisdom on your head as a crown, your rank and position would advance so high so that you can touch the sky.

The time when success was a crown upon the sage's head and wisdom a luxurious bracelet on their hand has long passed.

Place the hat of wisdom on your head one night and gaze upon the sky.
Table 9. Percentage and number of metaphors in the jewelry and attire domain

\begin{tabular}{|c|c|c|}
\hline $\begin{array}{c}\text { Items from Jewelry and } \\
\text { Attire Domain }\end{array}$ & $\begin{array}{c}\text { Total Number of } \\
\text { Metaphors }\end{array}$ & $\begin{array}{c}\text { Relative } \\
\text { Percentage }\end{array}$ \\
\hline 7 & 96 & $7.29 \%$ \\
\hline
\end{tabular}

\section{Halter and Constraint Domain}

Religious themes can be found in this domain:

How can I prevent the rope of wisdom being placed around the neck of my soul when I know it is wisdom that distinguishes me from a donkey?

Oh thou, who wisdom has placed an iron bridle made of knowledge on the mouth of your soul; I am addressing you!

If the bridle of your wisdom be subdued to desire, you become a wild and uncontrollable horse.

To tread the path of courage and knowledge, one has to use good nature and wisdom to saddle up and bridle one's horse of the mortal body.

If you want to halter the drunken horse of your mortal body, you have to use the rope of wisdom and the thread of knowledge.

In the horse track of life, use wisdom as the bridle of your tongue's horse.

Table 10. Percentage and number of metaphors in the halter and constraint domain

\begin{tabular}{|c|c|c|}
\hline $\begin{array}{c}\text { Items from Halter and } \\
\text { Constraint Domain }\end{array}$ & $\begin{array}{c}\text { Total Number of } \\
\text { Metaphors }\end{array}$ & $\begin{array}{c}\text { Relative } \\
\text { Percentage }\end{array}$ \\
\hline 6 & 96 & $6.25 \%$ \\
\hline
\end{tabular}

\section{Tools Domain}

Man has always been fascinated by how tools can assist us in our lives. Naser Khosrou has also tried to portray "wisdom" as a tool:

If you want to excavate the jewel of words from your inner mine, use the torch of religion and the pickax of wisdom.

According to the compass of wisdom, you are even more worthless than the point of the compass.

Table 11. Percentage and number of metaphors in the tools domain

\begin{tabular}{|c|c|c|}
\hline Items from Tools Domain & $\begin{array}{c}\text { Total Number of } \\
\text { Metaphors }\end{array}$ & $\begin{array}{c}\text { Relative } \\
\text { Percentage }\end{array}$ \\
\hline 2 & 96 & $2.08 \%$ \\
\hline
\end{tabular}

\section{Defense Domain}

The many wars and battles forced upon the Persian Empire required all people to acquaint themselves with defense mechanisms and firearms. The poet uses this knowledge to portray the defensive powers of "wisdom":

If one has wisdom as a fort to protect his soul, then he is made immune from the fire of ignorance.

I am not afraid of battling Satan; for worshipping God is my sword and wisdom my armor.

Piety and wisdom have placed me in a fort which protects me against the fire of hell and eternal torment.

In a dispute against your ideological opposition, your pen 
is your weapon, your reason the shield, wisdom as an army, and your words your army's flag.

Make a shield and helmet out of knowledge and wisdom, a club and cleaver from virtue and chastise.

My soul takes shelter in the fort of wisdom against the world and it is for this reason that it was never defeated.

Assign soldiers of wisdom and generosity on the walls of your soul's fort.

The heart is the center of your soul and you must set it as the gate of the fort of wisdom so that your soul can stay protected.

In facing the world's army and their sharp swords, religion and wisdom are the best army and shield.

Treading this path is not simple. Appoint the watchman of wisdom to council you on this path.

Do good deeds and wear the armor of virtue and wisdom; for there lays a hideous and huge dragon in your path.

Wisdom acts as a strong support against any danger. It destroys all pain and transforms all fear to security. It is the cure to all illnesses.

Wisdom is a true and virtuous friend for man in the path of life. It acts as a weapon against all danger.

Table 12. Percentage and number of metaphors in the defense domain

\begin{tabular}{|c|c|c|}
\hline $\begin{array}{c}\text { Items from Defense } \\
\text { Domain }\end{array}$ & $\begin{array}{c}\text { Total Number of } \\
\text { Metaphors }\end{array}$ & $\begin{array}{c}\text { Relative } \\
\text { Percentage }\end{array}$ \\
\hline 13 & 96 & $13.54 \%$ \\
\hline
\end{tabular}

\section{Medicine Domain}

The great advances in science at the time of Naser Khosrou have contributed to his including medicine as a domain:

This world is a dragon with poisonous fangs and God has appointed wisdom as an antidote so that you can protect yourself against this dragon.

In the eyes of the vigilant, wisdom is an antidote which can neutralize the poison of the dragon of time.

Like the wise, do not hesitate and promptly opt for paregoric wisdom to neutralize the effect of the bile of ignorance.

Wisdom acts as a strong support against any danger. It destroys all pain and transforms all fear to security. It is the cure to all illnesses.

Table 13. Percentage and number of metaphors in the medicine domain

\begin{tabular}{|c|c|c|}
\hline $\begin{array}{c}\text { Items from Medicine } \\
\text { Domain }\end{array}$ & $\begin{array}{c}\text { Total Number of } \\
\text { Metaphors }\end{array}$ & $\begin{array}{c}\text { Relative } \\
\text { Percentage }\end{array}$ \\
\hline 4 & 96 & $4.16 \%$ \\
\hline
\end{tabular}

\section{Rescue Domain}

Referring to parts of the Holy Quran (Muslim's Holy Book) is tactfully used in order to emphasize on the importance of "wisdom":

Your soul is held captive in the prison of this world. Wisdom wants to release it.

Free yourself from the chains of captivity and the fire of hell with the assistance of wisdom; even if most people would turn their backs on wisdom and want to live in ignorance like donkeys.

Anyone who is imprisoned by the worldly beast may only be set free with wisdom.

In the turbulent sea of this age, Wisdom is a rescue ship. Go on board and be save yourself from drowning.

The ignorant man is always in shackles and chains although the chains might not be observable. The wise man is always free although he might be in prison and shackles.

Table 14. Percentage and number of metaphors in the rescue domain

\begin{tabular}{|c|c|c|}
\hline $\begin{array}{c}\text { Items from Rescue } \\
\text { Domain }\end{array}$ & $\begin{array}{c}\text { Total Number of } \\
\text { Metaphors }\end{array}$ & $\begin{array}{c}\text { Relative } \\
\text { Percentage }\end{array}$ \\
\hline 5 & 96 & $5.20 \%$ \\
\hline
\end{tabular}

\section{Reprimand Domain}

Religious themes have always been fascinating for Iranians and so Naser Khosrou uses these ideas very tactfully to make the abstract idea of "wisdom" more concrete and appealing to the people:

When they place you in your grave, ask yourself about what your deeds in this world; for your soul and wisdom can interrogate you instead of God's angel of death.

Laughter is the result of ignorance. How can I laugh when wisdom has seized me by my collar and is interrogating me about my every deed?

Table 15. Percentage and number of metaphors in the reprimand domain

\begin{tabular}{|c|c|c|}
\hline $\begin{array}{c}\text { Items from Reprimand } \\
\text { Domain }\end{array}$ & $\begin{array}{c}\text { Total Number of } \\
\text { Metaphors }\end{array}$ & $\begin{array}{c}\text { Relative } \\
\text { Percentage }\end{array}$ \\
\hline 2 & 96 & $2.08 \%$ \\
\hline
\end{tabular}

\section{Supremacy and Glorification Domain}

Religious themes can be traced here as well:

You can be the master of the world and worldly matters if wisdom be your guiding pillar.

Glance at the world from the rooftop of wisdom; for you can find no rooftop as high and elevated as wisdom.

Table 16. Percentage and number of metaphors in the supremacy and glorification domain

\begin{tabular}{|c|c|c|}
\hline $\begin{array}{c}\text { Items from Supremacy and } \\
\text { Glorification Domain }\end{array}$ & $\begin{array}{c}\text { Total Number of } \\
\text { Metaphors }\end{array}$ & $\begin{array}{c}\text { Relative } \\
\text { Percentage }\end{array}$ \\
\hline 2 & 96 & $2.08 \%$ \\
\hline
\end{tabular}

\section{Miscellaneous Domain}

\section{Edible}

Possessing worldly blessings without religion and wisdom is not decent; just as having bread without cumin and oregano is not pleasing.

\section{Path and Route}

Not all are worthy of your company and you should not associate with everyone; however, this does not mean you should break away from everyone and live in solitude. Tread the path of wisdom and choose a middle road; do not 
be a fly or a phoenix (A fly is characterized by associating with all while the phoenix is a mythical bird of solitude).

\section{Shopping}

Seeking Wisdom should be accompanied by seeking knowledge and be sure that wisdom always purchases the product of knowledge.

\section{Value}

Wisdom is so valuable that God has praised man and has addressed him in His speech since wisdom was bestowed upon man.

\section{Discernment}

The only thing that God uses to distinguish us from beasts is wisdom.

\section{Chemistry}

Wisdom is alchemy. It transforms all evil deeds to decent ones and all pain and suffering to blessings. Wisdom is a justice and kindness mine.

\section{Marriage}

Oh child! Your body and soul are like a married couple and their dowry is wisdom.

\section{Friendship}

Wisdom is a true and virtuous friend for man in the path of life. It acts as a weapon against all danger.

\section{Mines}

Wisdom is alchemy. It transforms all evil deeds to decent ones and all pain and suffering to blessings. Wisdom is a justice and kindness mine.
Table 17. Percentage and number of metaphors in the miscellaneous domain

\begin{tabular}{|c|c|c|}
\hline $\begin{array}{c}\text { Items from Miscellaneous } \\
\text { Domain }\end{array}$ & $\begin{array}{c}\text { Total Number of } \\
\text { Metaphors }\end{array}$ & $\begin{array}{c}\text { Relative } \\
\text { Percentage }\end{array}$ \\
\hline 9 & 96 & $9.37 \%$ \\
\hline
\end{tabular}

The following two tables show the overall obtained results in one place in order to better compare the results.

The second section of the results pertains to the metaphors found in Ferdowsi's works. The results have been categorized in order to help with the overall comprehension of the metaphors. Each translated verse encompasses a bolded metaphor to help the reader. The specific reference in which the original verse (Persian) was found in is also mentioned after each verse. After each metaphor domain, a table including the statistical results will follow. Each of the domains reflects the prevalent thought patterns of people during the time Ferdowsi was composing his poetry. This can add to our better understanding of how masterful poets such as Ferdowsi tried to portray the thinking mechanisms of his time.

\section{Vegetation Domain}

Iranians have always had a close relationship with nature. This can be seen in the time of the New Year (Norouz) and many ceremonies held in nature to rejoice the changes in nature during different seasons. This can be a reason why Ferdowsi also opts for vegetation as a means to elaborate on wisdom. Here are the two verses which included Wisodm:

He behaves in a way so that the branches of religion and wisdom bear bountiful fruit by increasing his knowledge; his wisdom is also expanded.

The leaves of his soul are wise words and its fruit is wisdom; anyone who nourishes wisdom is immortalized.

Table 18. Percentage and number of Naser Khosrou's metaphors in all domains

\begin{tabular}{|c|c|c|c|c|c|c|c|c|}
\hline $\begin{array}{c}\text { Jewelry } \\
\text { and Attire }\end{array}$ & $\begin{array}{c}\text { Halter and } \\
\text { Constraint }\end{array}$ & Tools & Defense & Medicine & Rescue & $\begin{array}{c}\text { Supremacy } \\
\text { and } \\
\text { Glorification }\end{array}$ & Reprimand & Miscellaneous \\
\hline $7.29 \%$ & $6.25 \%$ & $2.08 \%$ & $13.54 \%$ & $4.16 \%$ & $5.20 \%$ & $2.08 \%$ & $2.08 \%$ & $9.37 \%$ \\
\hline
\end{tabular}

Table 19. Percentage and number of Naser Khosrou's metaphors in all domains

\begin{tabular}{|c|c|c|c|c|c|c|c|}
\hline Vegetation & Luminosity & $\begin{array}{c}\text { Guidance } \\
\text { and Reliance }\end{array}$ & Religion & $\begin{array}{c}\text { Flesh and } \\
\text { Physique }\end{array}$ & Birds & Evaluation & $\begin{array}{c}\text { Cleansing } \\
\text { and } \\
\text { Purification }\end{array}$ \\
\hline $10.41 \%$ & $5.20 \%$ & $7.29 \%$ & $2.08 \%$ & $4.16 \%$ & $4.16 \%$ & $8.33 \%$ & $6.25 \%$ \\
\hline
\end{tabular}


Table 20. Percentage and number of metaphors in the vegetation domain

\begin{tabular}{|c|c|c|}
\hline $\begin{array}{c}\text { Items from Vegetation } \\
\text { Domain }\end{array}$ & $\begin{array}{c}\text { Total Number of } \\
\text { Metaphors }\end{array}$ & $\begin{array}{c}\text { Relative } \\
\text { Percentage }\end{array}$ \\
\hline 2 & 29 & $6.89 \%$ \\
\hline
\end{tabular}

\section{Flesh and Physique Domain}

Due to the many advances in biology at the time, many poets such as Ferdowsi used the human anatomy to elaborate on abstract ideas such as "wisdom":

It was heard from the threshold of the king's palace. Thou unparalleled man! Never shut your eyes of wisdom.

You fight ruthlessly and shut your eye of wisdom.

Look through your eyes of wisdom and decide who is worthy of becoming your bride amongst these beauties.

Table 21. Percentage and number of metaphors in the flesh and physique domain

\begin{tabular}{|c|c|c|}
\hline $\begin{array}{c}\text { Items from Flesh and } \\
\text { Physique Domain }\end{array}$ & $\begin{array}{c}\text { Total Number of } \\
\text { Metaphors }\end{array}$ & $\begin{array}{c}\text { Relative } \\
\text { Percentage }\end{array}$ \\
\hline 3 & 29 & $10.34 \%$ \\
\hline
\end{tabular}

\section{Luminosity Domain}

In pursuing light man can become exalted and can become closer to his creator. and so this has great values in Persian Poetry. Here are the examples found in this regard:

Long live the world with his presence and wisdom shines on his rein and monarchy.

In order to worship God you have to wash your and with the candle of wisdom, search for His path.

Table 22. Percentage and number of metaphors in the luminosity domain

\begin{tabular}{|c|c|c|}
\hline $\begin{array}{c}\text { Items from Luminosity } \\
\text { Domain }\end{array}$ & $\begin{array}{c}\text { Total Number of } \\
\text { Metaphors }\end{array}$ & $\begin{array}{c}\text { Relative } \\
\text { Percentage }\end{array}$ \\
\hline 2 & 29 & $6.89 \%$ \\
\hline
\end{tabular}

\section{Guidance and Reliance Domain}

The Sufi thought patterns have greatly influenced Ferdowsi's poetry and the following verses portray this:

His thoughts and reflections perceive all and his stature has transformed into a pillar of wisdom.

From here on, focus only on those deeds which your soul and wisdom guides you.

I will do all good deeds that come to my mind and wisdom councils me on.

I pray wisdom be your soul's guide and your thoughts remain pure and chaste.

A ruler, who has wisdom as his council, can help Persia and the whole world thrive and prosper.

I pray you be immortal and live a prosperous life and wisdom be your council till the end of days.

Table 23. Percentage and number of metaphors in the guidance and reliance domain

\begin{tabular}{|c|c|c|}
\hline $\begin{array}{c}\text { Items from Guidance and } \\
\text { Reliance Domain }\end{array}$ & $\begin{array}{c}\text { Total Number of } \\
\text { Metaphors }\end{array}$ & $\begin{array}{c}\text { Relative } \\
\text { Percentage }\end{array}$ \\
\hline 6 & 29 & $20.68 \%$ \\
\hline
\end{tabular}

\section{Defense Domain}

Ferdowsi is an epic poet and so is interested in battles and firearms:

This war brings about pain and suffering. Sharpen your sword of wisdom and think of a remedy.

If a ruler be just and auspicious, then without a doubt, wisdom will be his guard.

Be at my beck and call and wear wisdom like armor.

Table 24. Percentage and number of metaphors in the defense domain

\begin{tabular}{|c|c|c|}
\hline $\begin{array}{c}\text { Items from Defense } \\
\text { Domain }\end{array}$ & $\begin{array}{c}\text { Total Number of } \\
\text { Metaphors }\end{array}$ & $\begin{array}{c}\text { Relative } \\
\text { Percentage }\end{array}$ \\
\hline 3 & 29 & $10.34 \%$ \\
\hline
\end{tabular}

\section{Jewelry and Attire Domain}

Jewelry and attire have been very important to the royalty and nobles of Ferdowsi's time and since he was the Ghaznavi's court poet, he was accustomed to such matters. He tried to entertain both the royalty and the commoners:

Covetousness and greed has leaned on the throne of wisdom. Why has the Devil become your partner?

Knowledge is my watchman and wisdom my enlightened crown.

A heart that is decorated with the garment of wisdom is a rich and valuable treasure.

Table 25. Percentage and number of metaphors in the jewelry and attire domain

\begin{tabular}{|c|c|c|}
\hline $\begin{array}{c}\text { Items from Jewelry and } \\
\text { Attire Domain }\end{array}$ & $\begin{array}{c}\text { Total Number of } \\
\text { Metaphors }\end{array}$ & $\begin{array}{c}\text { Relative } \\
\text { Percentage }\end{array}$ \\
\hline 3 & 29 & $10.34 \%$ \\
\hline
\end{tabular}

\section{Path and Route Domain}

Finding the right path to reach God has always been important to Persian Poets. It is no wonder this was used as a domain to make the idea of "wisdom" more concrete.

Whoever breaks his promise with me has deviated from the path of wisdom.

Never deviate from the path of wisdom; for your heart will soon regret it.

\begin{tabular}{|c|c|c|c|c|c|c|c|c|}
\hline Miscellaneous & Path & Jewelry & Cleansing & Defense & Guidance & Luminosity & Flesh & Vegetation \\
\hline $20.68 \%$ & $13.79 \%$ & $6.89 \%$ & $3.44 \%$ & $10.34 \%$ & $20.68 \%$ & $6.89 \%$ & $10.34 \%$ & $6.89 \%$ \\
\hline
\end{tabular}

I narrated a story so that the general could understand my intentions and return to the path of wisdom.

Unethical and immoral attitudes will deviate you from the path of wisdom. 
Table 26. Percentage and number of metaphors in the path and route domain

\begin{tabular}{|c|c|c|}
\hline $\begin{array}{c}\text { Items from Path and } \\
\text { Route Domain }\end{array}$ & $\begin{array}{c}\text { Total Number of } \\
\text { Metaphors }\end{array}$ & $\begin{array}{c}\text { Relative } \\
\text { Percentage }\end{array}$ \\
\hline 4 & 29 & $13.79 \%$ \\
\hline
\end{tabular}

\section{Loan Domain}

Traces of the Sufi lifestyle regarding the bestowment of knowledge from master to apprentice can be found here:

Narrate a story of passed kings and free yourself from the loan of wisdom.

I taught him the art of ruling a kingdom and with the advice I gave him I repaid my loan of wisdom.

Table 27. Percentage and number of metaphors in the loan domain

\begin{tabular}{|c|c|c|}
\hline Items from Loan Domain & $\begin{array}{c}\text { Total Number of } \\
\text { Metaphors }\end{array}$ & $\begin{array}{c}\text { Relative } \\
\text { Percentage }\end{array}$ \\
\hline 2 & 29 & $6.89 \%$ \\
\hline
\end{tabular}

\section{Miscellaneous Domain}

\section{Wild Beast}

Patience and wisdom are the elusive beasts who have evaded me. Tell me what should I do?

\section{Hunter}

Focus on deeds that are compatible with wisdom. Wisdom is a wild beast that tears a dragon's heart.

\section{Weaving}

Dear brother! Try to become one with wisdom and help your soul be the weft for the warp of wisdom.

\section{Irrigation}

Wisdom is water and knowledge a piece of land. These two are inseparable.

Table 28. Percentage and number of metaphors in the miscellaneous domain

\begin{tabular}{|c|c|c|}
\hline $\begin{array}{c}\text { Items from Miscellaneous } \\
\text { Domain }\end{array}$ & $\begin{array}{c}\text { Total Number of } \\
\text { Metaphors }\end{array}$ & $\begin{array}{c}\text { Relative } \\
\text { Percentage }\end{array}$ \\
\hline 4 & 29 & $13.79 \%$ \\
\hline
\end{tabular}

The following table shows the overall obtained results in one place in order to better compare the results.

Table 29. Percentage and number of Ferdowsi's metaphors in all domains

\section{Conclusions}

Based on the results presented in the previous section, the following conclusions can be attained:

1. As can be seen from the results, both poets have made use of a variety of domains pertaining to metaphors on wisdom and in many cases an overlap can be seen in the works of the two poets. In fact, both poets have used vegetation, flesh, luminosity, guidance and reliance, defense, cleansing and Purification, jewelry and attire, and path and route domains.

2. In the domain of vegetation, Ferdowsi has only used the word "fruit" once, while Naser Khosrou has used it 5 times. Both poets have used the word "branch" with Ferdowsi using it one time and Naser Khosrou, two times.

3. In the flesh and physique domain, both poets have focused on "eyes" and this has been used 3 times. In addition to the above, Naser Khosrou also uses "torso" in only one instance.

4. In the luminosity domain, the only common word referring to luminosity is "candle" and this has been used one time by Ferdowsi and 3 times by Naser Khosrou.

5. No commonality can be found in the domain of guidance and reliance.

6. Both poets have used the word "shield" as a common idea and have only used this once in their poems.

7. In the domain of path and route, Ferdowsi has used the word "path" 4 times and Naser Khosrou uses this word only once.

8. In the domain of jewelry and attire, no specific common word can be found; however, both poets have referred to the word "crown" which could express the highest rank in the body.

9. The guidance and reliance domain has been used most often by Ferdowsi ( 6 references), while Naser Khosrou focuses more on defense (13 references).

What the authors have tried to do in this paper was to identify, analyze, and categorize the various applications of the word "wisdom" in order to show its diversity in the poems of two Persian poets. It is hoped that this and similar studies can pave the way for more in depth research into Persian poetry and cognitive linguistics.

\section{REFERENCES}

[1] Al Jumah, F. H. (2007), A comparison study of metaphor in Arabic and English general business writing with teaching implications. Indiana University of Pennsylvania, Pennsylvania.

[2] Aristotle. (1954). Rhetoric. (Trans. by Rhys Roberts). New York: The Modern Library, Random House.

[3] Aristotle. (1982). Poetics. (Trans. by W. Hamilton Fyfe). Cambridge: Harvard University Press.

[4] Croft, W. \& Cruse A. D. (2004). Cognitive Linguistics. Cambridge: Cambridge University Press.

[5] Dehghanpisheh, E. (1979). Bridging the gap between controlled and free composition: Controlled rhetoric at the upper-intermediate level. TESOL Quarterly, 13(4), 509-519.

[6] Evans, V. \& Green, M. (2006). Cognitive Linguistics: An Introduction. Edinburgh: University Press.

[7] Evans, V., Bergen, B.K., \& Zinken, J. (2006). The cognitive 
linguistics enterprise: An overview. In The Cognitive Linguistics Reader, London: Equinox.

[8] Fauconnier, G. (2003). Cognitive Linguistics. In L. Nadel (Ed.) Encyclopedia of Cognitive Science. London: Macmillan.

[9] Fillmore, C.J. (1975). An alternative to checklist theories of meaning, Berkeley Linguistics Society, 1,123-131.

[10] Gibbs, R. (1994). The poetics of mind: Figurative thought, language, and understanding. New York: Cambridge University Press.

[11] Gibbs Jr., R.W. (2006). Cognitive linguistics and metaphor research: Past success, skeptical questions, future challenges. D.E.L.T.A., 22, 1-20.

[12] Gibbs, R., \& Steen, G. (1999). Metaphor in cognitive linguistics. Amsterdam: Benjamins.

[13] Harré, R. \& Gillett, G. (1994). The Discursive Mind. London, Sage Publications.

[14] Hilferty, J. (2001). Cognitive linguistics: An introductory sketch. La gramàtica i la semàntica en l'estudi de la variació (Actes del 5è i 6è col-loquis lingüístics de la Universitat de Barcelona (CLUB-5, CLUB-6), Mercè Lorente, Núria Alturo, Emili Boix, Maria-Rosa Lloret i Lluís Payrató, pp. 189-250. Barcelona: PPU.

[15] Imre, A. (2010). Metaphors in cognitive linguistics. Eger Journal of English Studies, 10 (2010), 71-81.

[16] Johnson, M. (1987). The body in the mind: The bodily basis of meaning, imagination, and reason. University of Chicago Press, Chicago.

[17] Johnson, M. (1991). Knowing Through the Body, Philosophical Psychology, 4(1),3-18.

[18] Kay, P. \& Fillmore, C.J. (1999). Grammatical constructions and linguisticgeneralizations: The what's $\mathrm{X}$ doing $\mathrm{Y}$ ? construction. Language, 75(1), 1-33.

[19] Lakoff, G. (1986). Cognitive Semantics, Versus, 44/45, 119 154.

[20] Lakoff, G. (1987). Women, Fire, and Dangerous Things: What Categories Revealabout the Mind, University of Chicago Press, Chicago.

[21] Lakoff, G. \& Johnson, M. (1980). Metaphors We Live By, The University of Chicago Press, Chicago.
[22] Lakoff, G. (1990). The invariance hypothesis: Is abstract reason based on image-schemas?, Cognitive Linguistics, 1(1), 39-74.

[23] Lakoff, G. \& Johnson, M. (1980). Metaphors We Live By. Chicago: University of Chicago Press.

[24] Lakoff, G. \& Johnson, M. (1999). Philosophy in the Flesh: The Embodied Mind and Its Challenge to Western Thought, Basic Books, New York.

[25] Lakoff, G. \& Thompson, H. (1975). Introduction to cognitive grammar. Proceedings of the 1st Annual Meeting of the Berkeley Linguistics Society (pp. 295-313).

[26] Berkeley, CA.: Berkeley Linguistics Society.

[27] Mac Cormac, E. R. (1985). A Cognitive Theory of Metaphor. Cambridge: The MIT Press.

[28] Reid, J. M. (1984). ESL composition: The linear product of American thought. College Composition and Communication, 35(4), 449-452.

[29] Rosch, E. (1975). Cognitive Representations of Semantic Categories. Journal of

[30] Experimental Psychology: General, 104 (3),192-233.

[31] Saneh, N. A. (2009). Intercultural rhetoric in higher education: The case of Iranian students' textual practices in North American graduate schools. University of Ottawa, Ottawa.

[32] Shea'r, \& Ahmadnazad, (1999). Annotated of Naser Khosrow. Tehran: Nashre Qatre.

[33] Sinha, C. (2001). Cognitive linguistics, psychology and cognitive science. In D. Geeraerts and H. Cuyckens (Eds.), Handbook of Cognitive Linguistics. Oxford: Oxford University Press.

[34] Sobhani, T. (2006). Hakim Abolghasem Ferdowsi's Shahnameh. Tehran: Rozaneh Publishing.

[35] Sweetser, E. (1990). From etymology to pragmatics: Metaphorical and cultural aspects of semantic structure. Cambridge: Cambridge University Press.

[36] Tendahl, M., \& Gibbs Jr., R.W. (2008). Complementary perspectives on metaphor: Cognitive linguistics and relevance theory. Journal of Pragmatics, 40 (2008) 18231864. 